\title{
Model bimbingan kelompok dengan teknik bermain peran untuk meningkatkan keterampilan sosial
}

\author{
Muhammad Junaedi Mahyuddin \\ Bimbingan dan Konseling, STKIP Muhammadiyah Enrekang \\ Email: tommuanemandar@gmail.com
}

(Diterima: 5-April-2016; di revisi: 13-Juni-2016; dipublikasikan: 28-Juni-2016)

\begin{abstract}
This study aims to: (1) know the description of how to do the group guidance, (2) know the students social skills, (3) create a group guidance model using role play technique to increase the students social skills. The methodoogy applied in the study is Research and Development (R\&D). The population of the study is the students of Grade 5 Athirah Primary School Makasssar which is 62 stduents. The technique sampling used in the study is purposive sampling which is applied to 8 of the students. The result of the wilcoxon statistic test shows that group guidance model using role play technique is effective to increase students social skills. The study suggests the teacher especially guidance and counseling teacher to optimalize the application of group guidance service using role play technique that function as the tool to help students to increase their social skills.
\end{abstract}

Keywords: Group Guidance; Role Play; Social Skills.

\begin{abstract}
Abstrak: Penelitian bertujuan untuk: (1) mengetahui gambaran pelaksanaan bimbingan kelompok, (2) mengetahui keterampilan sosial siswa, (3) menghasilkan model bimbingan kelompok dengan teknik bermain peran untuk meningkatkan keterampilan sosial siswa, Metode yang digunakan dalam penelitian ini adalah Research and Development (R\&D). Populasi penelitian ini adalah siswa kelas V SD Athirah Makassar yang berjumlah 62 siswa. Teknik pengambilan sampel dengan cara purposive sampling dan diujicobakan kepada 8 orang siswa. Hasil uji statistik wilcoxon menunjukkan, bimbingan kelompok dengan teknik bermain peran efektif untuk meningkatkan keterampilan sosial siswa. Disarankan bagi guru khususnya guru bimbingan dan konseling untuk mengoptimalkan pelaksanaan layanan bimbingan kelompok dengan teknik bermain peran sebagai sarana untuk membantu siswa khususnya dalam meningkatkan keterampilan siswa.
\end{abstract}

Kata Kunci: Bimbingan Kelompok; Bermain Peran; Keterampilan Sosial.

Copyright ( 92016 Universitas Negeri Makassar. This is an open access article under the CC BYNC-ND license (http://creativecommons.org/licenses/by-nc-nd/4.0/).

\section{PENDAHULUHAN}

Keterampilan sosial harus dikembangkan sejak dini (Sekolah Dasar) karena anak yang dapat melakukan hubungan sosial secara baik dengan lingkungannya akan memiliki dasar dan mempunyai kemampuan untuk meraih keberhasilan di masa yang akan datang, seperti yang dikemukakan oleh Cartledge \& Kiarei (2001: 40) "Social incompetence can lead to failure cycles and eventual poor school and adult outcomes","Keterampilan sosial perlu dikembangkan sejak dini untuk mencegah kegagalan dan kesulitan di masa sekolah dan masa dewasa kelak". Sejalan dengan pendapat Cartledge \& Kiarei (2001) dalam penelitiannya berpendapat bahwa keterampilan sosial siswa yang dimiliki individu berfungsi untuk mengatasi permasalahan-permasalahan yang timbul akibat dari berinteraksi. 
Menurut Moeslichatoen (2001: 4-5) bentuk keterampilan sosial anak di Taman Kanak-Kanak yang harus dikuasai dalam memenuhi tugas-tugas perkembangan berikutnya sehingga dapat berkembang secara sehat dan normal, antara lain: membina dan menanggapi hubungan antar pribadi dengan anak lain secara memuaskan, tidak suka bertengkar, tidak ingin menang sendiri, berbagi makanan ringan dan mainan, dan sering membantu. Akan tetapi tidak semua anak mampu menguasai bentuk keterampilan sosial dalam bersosialisasi.

Menurut Nurihsan \& Agustin (2011: 49) beberapa masalah sosial yang sering dialami anak adalah: anak ingin menang sendiri, sok berkuasa, tidak mau menunggu giliran bila bermain bersama, selalu ingin diperhatikan atau memilih-milih teman, agresif dengan cara menyerang orang atau anak lain, merebut mainan atau barang orang lain, merusak barang teman lain dan ketidakmampuan menyesuaikan dengan lingkungan baru.

Mencermati beberapa pendapat ahli yang dikemukakan di atas, permasalahan terkait rendahnya keterampilan sosial terjadi di Sekolah Dasar Athirah Makassar. Dari hasil observasi awal peneliti dan wawancara dengan Masnawati S.Pd (selaku guru BK) yang dilakukan di Sekolah Dasar Athirah Makassar pada awal bulan, 8 Februari 2012. Guru BK mengakui dalam kesehariannya di sekolah tersebut masih terdapat siswa yang menunjukkan perilakuperilaku yang terindikasi kesulitan dalam bersosialisasi dengan teman sebaya seperti tidak ingin bekerja sama dengan teman yang tidak dekat, menyembunyikan barang teman agar mendapat perhatian, tidak ingin mengajak bermain bersama dengan teman yang tidak dekat dengan siswa tersebut, persaingan antar siswa dalam hal benda-benda yang dimilikinya, sehingga sering menimbulkan konflik dan kecemburuan sosial. Hasil wawancara juga menunjukkan bahwa penyelenggaraan layanan bimbingan kelompok belum optimal, hal ini ditandai dengan penggunaan metode bimbingan kelompok masih berpusat pada guru BK, penanganan hanya sekedar pemberian motivasi dan pemberian nasehat dan pelaksanaan layanan bimbingan kelompok masih bersifat umum.

Tidak dikuasainya keterampilan sosial pada anak akan mempengaruhi proses belajar mengajar serta iklim yang ada di suatu kelas. Anak-anak yang kurang memiliki keterampilan sosial sangat memungkinkan untuk ditolak oleh rekan yang lain, tidak mampu bekerjasama, tidak mampu menyesuaikan diri, tidak mampu berinteraksi dengan baik, tidak dapat mengontrol emosi diri, tidak mampu berempati, tidak mampu mentaati aturan serta tidak mampu menghargai orang lain. Sebaliknya, terbinanya keterampilan sosial pada diri anak akan memunculkan penerimaan dari teman sebaya, penerimaan dari guru dan sukses dalam belajarnya.

Hasil penelitian Cartledge, Gwendolyn \& Kiarei, Mary W. (2001) rendahnya keterampilan sosial ini membuat anak kurang mampu menjalin interaksi secara efektif dengan lingkungannya dan memilih tindakan agresif sebagai strategi coping. Mereka cenderung mengganggap tindakan agresif merupakan cara yang paling tepat utnuk mengatasi permasalahan sosial dan mendapatkan apa yang mereka inginkan. Akibatnya, mereka sering ditolak oleh orang tua, teman sebaya, dan lingkungan.

Penelitian menyebutkan bahwa kecenderungan anak bermasalah dengan keterampilan sosialnya dipengaruhi karena faktor lingkungan, keluarga, persahabatan, solidaritas kelompok dan kemampuan menyesuaikan diri (Bakhtiar, 2015).

Sehubungan dengan pentingnya keterampilan sosial bagi anak, maka penelitian ini mengkhususkan untuk meningkatkan keterampilan sosial pada anak dengan cara menemukan model penanganan yang tepat. Peneliti akan menggunakan layanan bimbingan kelompok dengan teknik bermain peran sebagai model dalam penanganan keterampilan sosial yang rendah karena menurut Shertzer dan Stone (Romlah 2006: 2-3) menyimpulkan bahwa bimbingan kelompok bertujuan "....agar individu dapat memahami dirinya dan lingkungannya, dapat mengarahkan diri dan menyesuaikan diri dengan lingkungannya, dan dapat mengembangkan dirinya secara optimal untuk kesejahteraan dirinya dan kesejahteraan masyarakat". Winkel \& Hastuti (2006: 565) mengemukakan manfaat layanan bimbingan kelompok adalah mendapat kesempatan untuk berkontak dengan banyak siswa, memberikan informasi yang dibutuhkan oleh siswa, siswa dapat menyadari tantangan yang akan dihadapi, siswa dapat menerima dirinya setelah menyadari bahwa teman-temannya sering menghadapi persoalan, kesulitan dan tantangan yang kerap kali sama, dan lebih berani mengemukakan 


\section{4 | Jurnal Psikologi Pendidikan \& Konseling Vol. 2 No. 1 Juni 2016}

pandangannya sendiri bila berada dalam kelompok; diberikan kesempatan untuk mendiskusikan sesuatu bersama, lebih bersedia menerima suatu pandangan atau pendapat bila dikemukakan oleh seorang teman daripada yang dikemukakan oleh seorang konselor. Sedangkan pemilihan teknik bermain peran karena mempertimbangkan latar belakang sifat siswa yang dalam usia perkembangan anak sekolah dasar, yaitu senang bermain, dan mudah percaya dengan teman dekat.

Teknik bermain peran menurut Romlah (2006) teknik bermain peran adalah suatu alat belajar untuk mengembangkan keterampilanketerampilan dan pengertian-pengertian mengenai hubungan antar manusia dengan jalan memerankan situasi-situasi yang paralel dengan yang terjadi dalam kehidupan sebenarnya. Artinya, situasi yang diperankan adalah sesuai dengan kehidupan yang sebenarnya. Selain itu, dalam bermain peran menurut Joyce, $B$ et al (2012) siswa mengeksplorasi masalah-masalah tentang hubungan antar manusia dengan cara memainkan peran dalam situasi permasalahan kemudian mendiskusikan peraturan-peraturan secara bersama-sama, siswa bisa mengungkapkan perasaan, tingkah laku, nilai, dan strategi pemecahan masalah.

Salah satu keunggulan dari teknik bermain peran adalah melibatkan pengalaman anak, hal ini membuat anak merasakan hal yang baru sehingga mampu menciptakan ketertarikan anak dalam mengikuti kegiatan bermain peran. Selain hal tersebut, Brown (Setyawati, 2012: 23) juga mengungkapkan bahwa bermain peran digunakan untuk membantu individu mengembangkan pemahaman yang lebih baik terhadap diri mereka sendiri, orang lain, atau untuk latihan perilaku.

Berdasarkan uraian permasalahan, penelitian sebelumnya dan memperhatikan konsep bimbingan kelompok dan teknik bermain peran. Peneliti akan mengembangkan sebuah model bimbingan kelompok dengan menggunakan teknik bermain peran sebagai alat untuk meningkatkan keterampilan sosial siswa di Sekolah Dasar Athirah Makassar.

Berdasarkan permasalahan yang berkembang di atas, maka rumusan masalah dalam penelitian adalah: (1) Bagaimana pelaksanaan bimbingan kelompok di SD Athirah Makassar? (2) Bagaimana tingkat keterampilan sosial di SD Athirah Makassar? (3) Bagaimana model bimbingan kelompok dengan teknik bermain peran untuk meningkatkan keterampilan sosial siswa di SD Athirah Makassar?

Tujuan penelitian adalah (1) mengetahui gambaran pelaksanaan bimbingan kelompok (2) mengetahui keterampilan sosial siswa (3) menghasilkan model bimbingan kelompok dengan teknik bermain peran untuk meningkatkan keterampilan sosial siswa

\section{METODE}

Penelitian menggunakan metode deskriftif dengan pendekatan research and development. Metode penelitian pengembangan merupakan metode yang digunakan untuk menghasilkan produk tertentu, dan menguji keefektifan produk tersebut (Sugiyono, 2009: 407). Dasar pertimbangan penggunaan pendekatan ini adalah pendapat Borg and Gall (2003) a process used to develop and validate educational product yang artinya bahwa strategi penelitian dan pengembangan merupakan proses yang efektif untuk mengembangkan dan menvalidasikan produk pendidikan. Produk pendidikan yang dapat dihasilkan melalui pendekatan riset dan pengembangan adalah buku teks, film instruksional, program komputer, metode mengajar, dan berbagi program.

Produk yang dimaksud dalam penelitian ini adalah sebuah model bimbingan kelompok dengan teknik bermain peran untuk meningkatkan keterampilan sosial di Sekolah Dasar Athira Makassar. Kerangka isi dan komponen model disusun berdasarkan kajian konsep bimbingan kelompok, kajian konsep bermain peran, kajian konsep keterampilan sosial serta kajian empiris tentang kondisi aktual layanan bimbingan dan konseling khususnya layanan bimbingan kelompok di Sekolah Dasar Athira Makassar.

Pengembangan model bimbingan kelompok untuk meningkatkan keterampilan sosial siswa di Sekolah Dasar ini dibagi dalam 6 tahap. Hal ini dilakukan dengan alasan disesuaikan dengan kebutuhan penelitian. Enam tahapan tersebut adalah sebagai berikut: (1) tahap studi pendahuluan (2) tahap merumuskan model hipotetik (3) tahap uji kelayakan model hipotetik (4) tahap perbaikan model hipotetik (5) tahap uji coba terbatas (6) tahap tersusunnya model akhir. Ke enam tahapan pokok dalam pengembangan model bimbingan kelompok dengan 
menggunakan teknik bermain peran untuk meningkatkan keterampilan sosial siswa.

Produk yang diuji dalam penelitian pengembangan ini adalah model bimbingan kelompok dengan teknik bermain peran untuk meningkatkan keterampilan sosial siswa.

Desain uji coba dalam penelitian ini terdiri dari uji ahli atau uji pakar bimbingan kelompok, uji praktisi bimbingan kelompok serta uji coba terbatas atau uji efektifitas model bimbingan kelompok dengan teknik bermain peran.

Data hasil validasi praktisi ini, berupa pendapat, kritik dan saran akan dianalisis secara deskripsi dan dijadikan acuan dalam membuat revisi model pengembangan, sehingga model bimbingan kelompok dengan teknik bermain peran untuk meningkatkan keterampilan sosial siswa menjadi lebih baik.

Uji Keefektifan penelitian. Tujuan dari pelaksanaan uji keefektifan adalah untuk melihat apakah model pengembangan, yakni model bimbingan kelompok dengan teknik bermain peran efektif dalam meningkatkan keterampilan sosial siswa. Uji efektifitas dalam penelitian ini menggunakan desain one group pretest-posttest design.

Menurut Sugiyono (2009:111), uji keefektifan dalam desain one group pretestposttest design adalah dengan membandingkan hasil pretest dan posttest satu kelompok subyek penelitian saja tanpa ada kelompok pembanding. Berdasarkan uraian yang telah dikemukakan maka desain uji efektifitas one group pretest posttest design yang digunakan dapat digambarkan sebagai berikut:

Skema One Group Pretest Posttest Design

\begin{tabular}{ccc}
\hline Pretest & Variabel bebas & Pascatest \\
$\mathrm{Y}_{1}$ & $\mathrm{X}$ & $\mathrm{Y}_{2}$ \\
\hline
\end{tabular}

$\begin{array}{ll}\text { Keterangan: } & \\ \text { Pretest } \mathrm{Y}_{1} & \text { : tes sebelum perlakuan } \\ & \text { (treatment) } \\ \mathrm{X} & \begin{array}{l}\text { : perlakukan (treatment) } \\ \text { Pascatest } \mathrm{Y}_{2}\end{array} \\ & \begin{array}{l}\text { tes setelah mendapat } \\ \text { perlakuan (treatment) }\end{array}\end{array}$

Subjek uji ahli model pengembangan pada penelitian ini adalah dua orang ahli/ pakar bimbingan kelompok.

Subjek uji praktisi model pengembangan pada penelitian ini adalah dua orang praktisi layanan bimbingan kelompok, yakni guru bimbingan dan konseling di sekolah yang menjadi lokasi pada penelitian ini.

Subjek uji coba dalam penelitian ini adalah siswa di Sekolah Dasar Athira Makassar. Dalam penelitian ini, jenis sampel yang digunakan adalah purposive sampling (pengambilan sampel berdasarkan tujuan). Sampel bertujuan untuk mencapai tujuan tertentu. Tujuan yang ingin dicapai adalah untuk meningkatkan keterampilan sosial siswa. subjek penelitian ini ditetapkan pada siswa-siswi Di Sekolah Dasar Athira Makassar. Dasar penetapannya adalah berdasarkan informasi dari guru BK bahwa di Sekolah tersebut memiliki keterampilan sosial yang rendah.

Subyek yang menjadi peserta penelitian berjumlah 8 siswa. Subyek penelitian ini dipilih berdasarkan skala tingkat keterampilan sosial yang dikembangkan oleh peneliti dengan melibatkan subyek-subyek yang memiliki tingkat keterampilan sosial yang rendah, sedang dan tinggi.

Jenis data yang digali dalam penelitian pengembangan ini adalah mengenai kalayakan dan keefektifan model layanan bimbingan kelompok dengan teknik bermain peran untuk meningkatkan keterampilan sosial siswa di Sekolah Dasar Athira Makassar.

Ada dua jenis yang akan digunakan dalam penelitian ini, yaitu data primer dan data sekunder. Data primer dalam penelitian digali dan diperoleh dari sumber pertama, yaitu pedoman wawancara dan observasi serta skala psikologis sebagai instrumen utama untuk mengetahui tingkat keterampilan sosial siswa. Dan instrumen validasi. Yang kedua adalah Data Sekunder, Jenis data sekunder digali dan diperoleh dari buku, jurnal ilmiah, hasil penelitian, yang ditulis para pakar pendidikan khususnya pakar bimbingan konseling, guna menganalisis keterampilan sosial.

Instrumen pengumpulan data yang digunakan dalam penelitian ini antara lain: Pedoman wawancara, Observasi, dan Skala psikologis keterampilan sosial . Instrumen skala psikologis keterampilan sosial yang digunakan dikembangkan berdasarkan pada skala Likert, 
skala tersebut digunakan untuk mengetahui tingkat keterampilan sosial siswa yang dilakukan sebelum diberikan treatment (melalui pre-test) dan setelah diberikan treatment (post-test). Format yang digunakan terdiri dari 4 pilihan jawaban sebagai berikut : SS (Sangat Sesuai), S (Sesuai), KS (Kurang Sesuai) dan TS (Tidak Sesuai).

Validitas dan reliabilitas instrumen penelitian. Sugiyono (2011:168) menjelaskan bahwa instrumen yang valid berarti alat ukur yang digunakan untuk mendapatkan data (mengukur) itu valid.

Menurut Arikunto (2006: 168) validitas adalah suatu ukuran yang menunjukan tingkat kevalidan dan kesahihan suatu instrumen. Suatu instrumen yang valid atau sahih mempunyai validitas yang tinggi, sebaliknya instrumen yang kurang valid berarti memiliki validitas yang rendah. Suatu instrumen dikatakan valid apabila dapat mengungkap data dari variabel yang diteliti secara tepat. Tinggi rendahnya instrument menunjukkan sejauh mana data yang terkumpul tidak menyimpang dari gambaran tentang validitas yang dimaksud.

Untuk menguji validitas dalam penelitian ini, penulis menggunakan validitas internal yang dapat dicapai apabila terdapat kesesuaian antara bagian-bagian instrumen atau butir-butir pernyataan dengan instrumen secara keseluruhan. Pengujian validitas dilakukan dengan analisis butir (anabut) rumus yang digunakan dalam pengujian validitas dengan menggunakan rumus product moment dari Pearson (Arikunto, 2006: 170) Rumus:

$$
\mathrm{r}_{\mathrm{xy}}=\frac{\mathrm{N} \sum \mathrm{XY}-\left(\sum \mathrm{X}\right)\left(\sum \mathrm{Y}\right)}{\sqrt{\left\{\mathrm{N} \sum \mathrm{X}^{2}-\left(\sum \mathrm{X}^{2}\right)\right\}\left\{\mathrm{N} \sum \mathrm{Y}^{2}-\left(\sum \mathrm{Y}^{2}\right)\right\}}}
$$

Keterangan:

$\mathrm{r}_{x y}=$ koefisien korelasi antara skor butir dengan skor total

$\sum X=$ jumlah skor butir

$\sum \mathrm{Y}=$ jumlah skor total

$\sum X Y=$ jumlah hasil perkalian skor butir dengan skor total

$\sum \mathrm{Y}^{2}=$ jumlah kuadrat skor total

keterbukaan diri

$\sum X^{2}=$ jumlah kuadrat skor butir

keterbukaan diri

$\mathrm{N}$ = banyaknya subyek
Uji validitas digunakan untuk melihat apakah butir-butir soal tersebut sahih atau valid. Harga $r_{x y}$ dibandingkan dengan $r$ tabel pada tingkat kepercayaaan 5\%.

Menurut Arikunto (2006: 178) reliabilitas adalah suatu instrumen dapat dipercaya untuk digunakan sebagai alat pengumpul data karena instrumen tersebut sudah baik. Sebuah alat ukur dikatakan reliabel apabila alat ukur digunakan dua kali atau lebih untuk mengukur sejumlah subyek yang sama dan waktu yang berbeda dan hasil yang diperoleh relatif sama. Untuk mengukur reliabilitas pada penelitian ini digunakan rumus Alpha Cronbach yaitu:

$$
\mathrm{r}_{11}=\left[\frac{k}{k-1}\right]\left[1-\frac{\sum \sigma_{b^{2}}}{\sigma^{2} t}\right]
$$

Keterangan:

$$
\begin{array}{ll}
\mathrm{r}_{11} & =\text { Reliabilitas instrument. } \\
\mathrm{k} & =\text { Banyaknya butir soal atau } \\
\text { butir pertanyaan } & \\
\sum \sigma_{b^{2}} & =\text { Jumlah varians butir } \\
\sigma^{2}{ }_{t} & =\text { Varians total }
\end{array}
$$

Menurut Arikunto (2006:196) rumus Alpha Cronbach digunakan untuk mencari reliabilitas instrument yang skornya bukan 1 dan 0 misalnya bentuk skala $1-3,1-5$ atau 1-7 dan seterusnya. Dalam penelitian ini skor angket berbentuk skala 1-4. Maka Analisis reliabilitas pada pada penelitian ini yaitu instrument keterbukaan diri menggunakan rumus Alpha Cronbach. Perhitungan reliabilitas dilakukan dengan menggunakan bantuan komputer program SPSS (Statistical Package For Social Sciens) For Windows versi 15,0.

Menurut Arikunto (2006: 86) perbedaan $\mathrm{O} 1$ dan $\mathrm{O} 2$ yakni O2-O1 diasumsikan merupakan efek dari treatment atau eksperimen. Arikunto (2006: 306) menambahkan apabila akan membandingkan kedua hasil dengan membandingkan mean. Arikunto (2006: 306) juga menambahkan untuk menganalisis hasil eksperimen yang menggunakan Pre-test dan Post-test One Group Design. Rumus:

$$
t=\frac{\mathbf{M d}}{\sqrt{\frac{\sum \mathrm{x}^{2} \mathrm{~d}}{\mathrm{~N}(\mathrm{~N}-1)}}}
$$

Keterangan:

Md = mean dari perbedaan/deviasi (d) antara post-test dan pre-test. 
$\mathrm{Xd}=$ deviasi dengan masing-masing subyek (d-Md).

$\mathrm{N} \quad=$ banyaknya subyek.

$\sum \mathrm{xd} \quad=$ jumlah kuadrat deviasi

Df = atau d.b. ditentukan dengan N-1

Menurut Sugiyono (2011) untuk mengetahui efektifitas atau untuk membuktikan signifikansi model bimbingan kelompok dengan teknik bermain peran (role playing) untuk meningkatkaan keterampilan sosial siswa digunakan uji beda rata-rata (uji-t) antara hasil pretest dan posttest.

\section{HASIL DAN PEMBAHASAN}

Berdasarkan hasil penelitian, yang dilaksanakan pada studi pendahuluan tentang pelaksanaan bimbingan kelompok di Sekolah Dasar Athirah kemudian hasil studi pendahuluan tersebut dijadikan bahan pertimbangan dalam membuat model bimbingan kelompok dengan teknik bermain peran untuk meningkatkan keterampilan sosial siswa Sekolah Dasar Athirah Makassar. Isi paparan yang disajikan meliputi: (1) pelaksanaan bimbingan kelompok (2) hasil model bimbingan model bimbingan kelompok dengan teknik bermain peran, dan 3) efektivitas model bimbingan kelompok dengan teknik bermain peran.

Kondisi Objektif Pelaksanaan Layanan Bimbingan kelompok di Sekolah Dasar Athirah Makassar. Hasil studi pendahuluan untuk mengetahui implementasi aktual pelaksanaan bimbingan kelompok dilakukan dengan melakukan observasi dan wawancara terhadap 2 (dua) orang guru BK di Sekolah Dasar Athirah Makassar. Hasil wawancara tersebut dapat dianalisis dalam beberapa aspek, yaitu: (1) penyusunan program bimbingan dan konseling yang terdiri dari need assesment dan pihak yang dilibatkan dalam penyusunan program BK (2) pelaksanaan program yang terdiri dari pelaksana program, rasio guru BK dengan jumlah siswa, kompetensi guru BK, keterlaksanaan bimbingan kelompok, tujuan pelaksanaan bimbingan kelompok, komponen bimbingan kelompok, dan tahap-tahap pelaksanaan bimbingan kelompok, (3) fasilitas bimbingan dan konseling (4) faktor penunjang dan penghambat pelaksanaan bimbingan kelompok (5) evaluasi dan tindak lanjut (6) dukungan sistem.

Hasil Studi Pendahuluan Untuk Merancang Hipotetik Model. Berdasarkan kajian empirik pada studi lapangan dapat dideskripsikan mengenai beberapa hasil yaitu Pelaksanaan layanan bimbingan kelompok bersifat insidental hal ini berdampak pada pelaksanaan bimbingan kelompok yang kurang persiapan, sehingga hasil yang diperoleh dari pelaksanaan tersebut kurang maksimal.

Dari keterampilan sosial yang dialami siswa, guru BK belum pernah memberikan bimbingan kelompok di SD Athirah Makassar, hal ini disebabkan karena guru BK atau konselor belum mempersiapkan secara khusus tentang pembahasan dalam menangani keterampilan sosial siswa tertentu.

Hasil Pengembangan. Bimbingan kelompok dengan teknik bermain peran ini dikembangkan berdasarkan analisis panduan antara temuan empirik dilapangan yakni kondisi objektif lapangan dengan kaidah-kaidah bimbingan kelompok yang bersifat konseptual yakni kajian teoritik dan hasil-hasil penelitian, dan ketentuan formal pelaksanaan layanan bimbingan kelompok. 
Tabel 4.23 Perbandingan skor pre-test dan post-test secara keseluruhan

$\begin{array}{lccccc}\text { No } & \text { Siswa } & \begin{array}{c}\text { Skor pre } \\ \text { test }\end{array} & \text { Kategori } & \begin{array}{c}\text { Skor } \\ \text { post test }\end{array} & \text { Kategori } \\ \mathbf{1} & \text { AB } & 77 & \text { Sangat rendah } & 96 & \text { Rendah } \\ \mathbf{2} & \text { AT } & 111 & \text { Rendah } & 122 & \text { Tinggi } \\ \mathbf{3} & \text { AR } & 131 & \text { Tinggi } & 144 & \text { Tinggi } \\ \mathbf{4} & \text { NA } & 106 & \text { Rendah } & 118 & \text { Tinggi } \\ \mathbf{5} & \text { FD } & 76 & \text { Sangat rendah } & 93 & \text { Rendah } \\ \mathbf{6} & \text { DW } & 83 & \text { Rendah } & 98 & \text { Rendah } \\ \mathbf{7} & \text { HD } & 112 & \text { Tinggi } & 122 & \text { Tinggi } \\ \mathbf{8} & \text { ID } & 159 & \text { Sangat tinggi } & 166 & \text { Sangat tinggi } \\ & \text { Jumlah } & 855 & & 959 & \end{array}$

Dari data diatas, terlihat bahwa terjadi peningkatan skor keterampilan sosial siswa sebelum (pre-test) diberikan layanan bimbingan kelompok dengan teknik bermain peran dibandingkan dengan skor keterampilan sosial setelah (post-test) diberikan layanan bimbingan kelompok dengan teknik bermain peran.

Secara keseluruhan, dari 8 siswa yang diberi bimbingan kelompok dengan teknik bermain peran mengalami kenaikan 104 poin pada skor keterampilan sosial siswa atau sebesar $12.16 \%$.

Untuk memperoleh gambaran yang lebih jelas tentang perbandingan keterampilan sosial sebelum (pre-test) dan setelah (post-test) di Sekolah Dasar Athirah Makassar, peneliti memaparkan ke dalam bentuk diagram batang, sebagaimana tertera pada grafik di bawah ini:

Grafik 4.6 Peningkatan keterampilan sosial siswa pada skor total

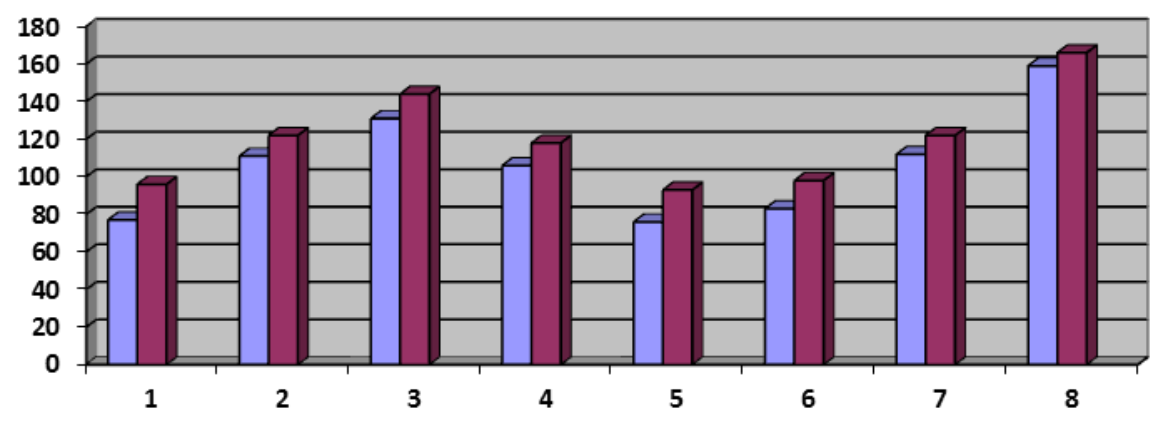

Perubahan tingkat keterampilan sosial siswa antara sebelum (pre-test) dan sesudah (post-test) menunjukkan perubahan yang signifikan, ditandai dengan adanya peningkatan skor skala keterampilan sosial siswa, baik pada skor total maupun skor setiap indikator.

Pembahasan Hasil Penelitian dan Produk Akhir. Pembahasan yang dimaksud pada bagian ini berdasarkan pada hasil penelitian yang telah di kemukakan diatas yaitu, tentang gambaran proses pelaksanaan bimbingan kelompok dan efektifitas layanan bimbingan kelompok dengan teknik bermain peran. Langkah awal dalam struktur dan komponen model layanan bimbingan kelompok dengan teknik bermain peran ini adalah mengkaji tentang aktualitas bimbingan kelompok dan keterampilan sosial siswa di Sekolah Dasar Athirah Makassar melalui metode wawancara, observasi dan penyebaran skala psikologis.

Hasil uji lapangan model bimbingan kelompok teknik bermain peran menunjukkan bahwa: (1) guru BK memiliki wawasan baru tentang model bimbingan kelompok yang belum ada di sekolah, guru BK dalam merencanakan bimbingan kelompok lebih memperhatikan aspek perkembangan, kebutuhan siswa, masalah siswa, kelayakan tempat dan waktu pelaksanaan (2) model bimbingan kelompok dengan teknik bermain peran dapat diimplementasikan dengan baik pada Sekolah Dasar Athirah Makassar (3) 


\section{0 | Jurnal Psikologi Pendidikan \& Konseling Vol. 2 No. 1 Juni 2016}

Setelah pelaksanaan layanan bimbingan kelompok dengan teknik bermain peran dilaksanakan, memberikan dampak positif bagi siswa, siswa merasa senang, menambah pemahaman yang belum ia peroleh di kelas, lebih menghargai orang lain, berani bertanggung jawab dan menjadikan motivasi diri untuk lebih baik dari sebelumnya (4) Adanya kerja sama antar komponen lainya di lingkungan sekolah untuk tentang pemahaman layanan bimbingan kelompok.

\section{SIMPULAN DAN SARAN}

Berdasarkan hasil analisis data, mulai dari tahap penelitian pendahuluan hingga tahap uji coba model dapat disimpulkan bahwa:

1. Pelaksanaan bimbingan kelompok di Sekolah Dasar Athirah Makassar telah dilaksanakan oleh konselor akan tetapi belum maksimal, bimbingan kelompok yang dilaksanakan masih bersifat umum, yaitu hanya diskusi umum belum menggunakan pendekatan ataupun teknikteknik khusus, materi/topik yang dibahas tidak terfokus pada keterampilan sosial secara spesifik, sehingga proses pemecahan masalah menjadi tidak fokus.

2. Berdasarkan hasil penyebaran instrumen skala psikologis keterampilan sosial, diketahui bahwa keterampilan sosial dari 62 siswa kelas V Sekolah Dasar Athirah Makassar, $8.06 \%$ siswa tergolong kategori sangat rendah, $40.32 \%$ kategori rendah dan $38.71 \%$ kategori tinggi, sedangkan $12.90 \%$ untuk kategori sangat tinggi. Agar keterampilan sosial siswa dapat ditingkatkan perlu adanya pengembangan model bimbingan kelompok dengan teknik bermain peran.

3. Telah dikembangkan model bimbingan kelompok dengan teknik bermain peran untuk meningkatkan keterampilan sosial siswa yang telah melewati proses validasi secara akademik atau ahli bimbingan dan konseling serta validasi oleh praktisi. Komponen model bimbingan kelompok dengan teknik bermain peran untuk meningkatkan keterampilan sosial siswa, yang terdiri dari 13 komponen sebagai berikut: (1) rasional, (2) visi misi, (3) konsep kunci yang terdiri dari: (1) pengertian bimbingan kelompok, b) pengertian teknik bermain peran, c) pengertian keterampilan sosial, d) pengertian bimbingan kelompok dengan teknik bermain peran, (4) tujuan model bimbingan kelompok dengan teknik bermain peran, (5) isi model, (6) dukungan sistem yang terdiri dari: (a) pengembangan program, (b) pengembangan staf, (c) kebijaksanaan dan teknis pelaksanaan, (7) prosedur kerja, (8) anggota kelompok, (9) topik/materi, (10) suasana interaksi, (11) tahap-tahap pelaksanaan, (12) media, (13) evaluasi.

Berdasar pada kesimpulan penelitian sebagaimana yang telah dikemukakan di atas, maka dapat dikemukakan beberapa saran, yaitu: Pihak Sekolah, Sekolah dapat memberikan perhatian dan dukungan dengan menjadikan bimbingan kelompok dengan teknik bermain peran sebagai salah satu kegiatan yang penting untuk dikembangkan berbagai aspek, khususnya perkembangan keterampilan sosial siswa. Guru Sekolah, Menerapkan bimbingan kelompok dengan teknik bermain peran sebagai metode bimbingan kelompok untuk mengatasi rendahnya keterampilan sosial siswa. Peneliti selanjutnya, Hasil penelitian model bimbingan kelompok dengan teknik bermain peran ini, secara konseptual memberi kontribusi secara teoretis yaitu sebagai perluasan khasanah keilmuan tentang konsep dan praktik bimbingan dan konseling khususnya dalam layanan bimbingan kelompok, yang dapat dijadikan sebagai salah satu referensi oleh peneliti di masa mendatang dan tidak menutup kemungkinan dapat dikembangkan untuk mengangkaji pada aspek perkembangan yang lain yang ada pada diri siswa.

\section{DAFTAR RUJUKAN}

Arikunto, Suharsimi.(2006). Prosedur Penelitian suatu Pendekatan Praktek. Jakarta: Rineka Cipta

Borg, W.R dan Gall, M.D. (2003). Educational Research, an Introduction Fourth Edition. New York: Logman. Inc.

Bakhtiar, M. I. (2015). Pengembangan Video Ice Breaking Sebagai Media Bimbingan 
Konseling. Jurnal Psikologi Pendidikan

Dan Konseling, 1(2), 150-163. Retrieved from http://ojs.unm.ac.id/index.php/JPPK/arti cle/view/1816

Cartledge, G \& Kiarei, Mary W. (2001). Learning Social Skills Through Literature For Children and Adolescent. Teaching Exceptional Children Journal. 34, (2), 40-47.

Joyce, B et al. (2012). Models of Teaching. Yogyakarta: Pustaka Pelajar.

Moeslichatoen. (2004). Metode Pengajaran di Taman Kanak-kanak. Jakarta: Rineka Cipta.

Nurihsan, A. J. (2006). Bimbingan dan Konseling dalam Berbagai Latar Kehidupan. Bandung: Refika Aditama

Nurihsan, A.J \& Agustin. (2011). Dinamika perkembangan anak dan remaja (tinjauan Psikologi Pendidikan dan bimbingan). Bandung. Rafika Aditama.
Romlah, T. (2006).Teori dan Praktik Bimbingan Kelompok. Malang: UM Press.

Setyawati. (2012). Program Bimbingan Melalui Teknik Role Playing Untuk Meningkatkan Self-Efcacy Karir Peserta Didik. Tesis. Repository UPI.

Sugiyono. (2009). Metode Penelitian Pendidikan, pendekatan Kuantitatif , kualitatif dan $R \quad \& D$. Bandung: Alfabeta.

Sugiyono. (2011). Metode Penelitian Kombinasi (Mixed Method). Bandung: Alfabeta.

Sukmadinata, N.S. (2007). Bimbingan dan Konseling dalam Praktik Mengembangkan Potensi dan Kepribadian Siswa. Bandung: Maestro.

Winkel \& Hastuti. S. (2006). Bimbingan dan Konseling di Institusi Pendidikan. Yogyakarta 